\title{
A new species of nocturnal gecko (Paroedura) from karstic limestone in northern Madagascar
}

\author{
Frank Glaw ${ }^{1}$, Herbert Rösler $^{2}$, Ivan Ineich ${ }^{3}$, Philip-Sebastian Gehring ${ }^{4}$, Jörn Köhler ${ }^{5}$, Miguel Vences ${ }^{6}$ \\ 1 Zoologische Staatssammlung München, Münchhausenstr. 21, 81247 München, Germany \\ 2 Staatliche Naturhistorische Sammlungen Dresden, Museum für Tierkunde, Forschungsstelle, A. B.-Meyer Bau, Königsbrücker Landstr. 159, \\ 01109 Dresden, Germany \\ 3 Muséum national d'Histoire naturelle, ISYEB (Institut de Systématique, Évolution et Biodiversité), UMR 7202 (CNRS, EPHE, MNHN, UPMC), \\ CP 30 (Reptiles), 57 rue Cuvier, 75005 Paris, France \\ 4 Diesterwegstr. 20, 33604 Bielefeld, Germany \\ 5 Hessisches Landesmuseum Darmstadt, Friedensplatz 1, 64283 Darmstadt, Germany \\ 6 Zoological Institute, Technical University of Braunschweig, Mendelssohnstr. 4, 38106 Braunschweig, Germany
}

http://zoobank.org/CC6E4851-C6FD-4B47-973E-3E045390B579

Corresponding author: Frank Glaw (Frank.Glaw@zsm.mwn.de)

\begin{abstract}
Received 6 October 2014

Accepted 17 October 2014

Published 5 November 2014

Academic editor:

Matthias Glaubrecht

\section{Key Words}

Squamata

Gekkonidae

Paroedura

new species

Madagascar

Montagne des Français

conservation

Paroedura hordiesi sp. n. is described from Montagne des Français, a karstic limestone massif in the far north of Madagascar recently established as nature reserve. The new species has the nostril in contact with the rostral scale and shares many characters with $P$. karstophila and especially with P. homalorhina which are also restricted to karstic habitats. Paroedura hordiesi differs from P. karstophila by a smoother skin on dorsum and legs, by original and regenerated tails being both entirely smooth, by colouration, and by larger snout-vent length. Morphologically the new species is most similar to $P$. homalorhina from the Ankarana reserve from which it can be distinguished by shorter limbs and a less slender habitus. Published molecular data place the new species as close relative of $P$. homalorhina and another undescribed species from Nosy Hara Island, while newly determined data of the cox 1 gene for P. karstophila confirm the distinctness of the new species from this taxon. Integrating the information from published and novel molecular data, the new species differs from all nominal Paroedura (except $P$. vahiny for which no molecular data are available to date) by strong genetic divergences. $P$. hordiesi might be another microendemic species of the Montagne des Français region. We suggest its IUCN Red List classification as "Critically Endangered" on the basis that it has an extent of occurrence of at most $50 \mathrm{~km}^{2}$, it is known from a single location, and there is a continuing decline in the extent and quality of its habitat.
\end{abstract}

\section{Introduction}

The far north of Madagascar comprises a mosaic of heterogeneous landscapes ranging from rainforests on volcanic basement to deciduous dry forests in karstic massifs and littoral habitats on sandy ground (e. g. Lavranos et al. 2001, Vences et al. 2009, Crottini et al. 2012). The geological and climatic diversity of this area is reflected by a high species diversity and a high degree of microendemism (e. g. Andreone 2004, Wilmé et al. 2006, Ranaivoarisoa et al.
2013). Endemism is usually restricted to the species level but one monotypic family of blindnakes (Xenotyphlopidae) is also endemic to this area (Wegener et al. 2013). Many new species of amphibians and especially reptiles have been discovered and described from far northern Madagascar in recent years, both from humid rainforests of the Montagne d'Ambre massif (e. g. Raxworthy and Nussbaum 2006, Glaw et al. 2007, 2010, Köhler et al. 2008, D’Cruze et al. 2010, Ratsoavina et al. 2011) and from the region around the dry karst forest formation of 
Montagne des Français and adjacent littoral habitats (Ramanamanjato et al. 1999, Raselimanana et al. 2000, Glaw et al. 2001, 2005, 2012, 2013, Köhler et al. 2010a, 2010b, Miralles et al. 2011). These major habitat types are separated from each other by rather steep ecotones in northern Madagascar and thus in part constitute "habitat islands" for several species, possibly allowing allopatric speciation. Several taxa including dwarf frogs (Stumpffia), dwarf chameleons (Brookesia), burrowing skinks (Paracontias), leaf-tail geckos (Uroplatus), and the nocturnal geckos of the genus Paroedura have undergone remarkable diversification in northern Madagascar (Jackman et al. 2008, Köhler et al. 2010a, 2010b, Ratsoavina et al. 2011).

The genus Paroedura is widely distributed throughout Madagascar's biomes, including eastern rainforest, western dry forest, extremely arid thornbush savanna and high mountain habitats (Angel 1942, Guibé 1956, Dixon and Kroll 1974, Rösler and Krüger 1998, Nussbaum and Raxworthy 2000). Five of the 15 described species from Madagascar occur in the far north, and two additional species from the Comoro islands have close relationships to the northern $P$. lohatsara and $P$. stumpffi suggesting that they originated by two colonization events from the northern species (Hawlitschek and Glaw 2013). Recent surveys indicate that the karstic limestone massifs in this region still harbour further undescribed reptile species (e. g. Jackman et al. 2008, Recknagel et al. 2013). Some of them might be microendemic and threatened by substantial habitat destruction. In the following we describe a new Paroedura species from Montagne des Français to contribute to the taxonomic inventory of this massif, and to highlight the threats affecting this microendemic species and other biota in the region.

\section{Methods}

Specimens were anesthetized by injection with chlorobutanol, fixed with $96 \%$ ethanol and stored in $70 \%$ ethanol. Terminology and abbreviations of characters partly follow Nussbaum and Raxworthy (2000). Abbreviations used: $\mathrm{MNHN}=$ Muséum national d'Histoire naturelle, Paris; UADBA = Université d'Antananarivo, Département de Biologie Animale; ZSM = Zoologische Staatssammlung, München; SVL = snout-vent length. All measurements were taken with a caliper to the nearest $0.1 \mathrm{~mm}$.

To obtain molecular comparisons of the new species with previously unstudied nominal Paroedura species, we sequenced a fragment of the mitochondrial gene for cytochrome oxidase subunit I (cox1) with primers and protocols defined by Nagy et al. (2012) for several Paroedura samples from Tsingy de Namoroka (corresponding voucher specimens to be catalogued in MNHN). These samples have become available through a recent herpetological survey by one of us (II) and include topotypical $P$. karstophila, previously unstudied from a molecular perspective. The resulting sequences were combined with those of Nagy et al. (2012) and Koubová et al. (2014) in
MEGA version 5 (Tamura et al. 2011) to yield an alignment of $664 \mathrm{bp}$. We performed phylogenetic inference in MEGA under the Maximum Likelihood optimality criterion, with a general time-reversible substitution model with gamma-distributed rates and invariant sites, NNI branch swapping, and assessing robustness of nodes with 500 bootstrap replicates. Newly obtained sequences were submitted to GenBank (accession numbers: KM978078KM978080).

\section{Results}

\section{Molecular differentiation in the genus Paroedura}

The multigene phylogenies of Jackman et al. (2008) and Hawlitschek and Glaw (2013) as well as the combined cox1 sequences of Nagy et al. (2012), Koubová et al. (2014) and those newly obtained (Fig. 1) provide evidence of strong genetic divergence of $P$. hordiesi to all other described Paroedura species except $P$. vahiny for which DNA sequence data is not yet available.

The cox 1 data place the new species sister to an undescribed candidate species from Nosy Hara (79\% bootstrap support), and this clade forms part of a more inclusive clade with $P$. oviceps and the undescribed Ankarafantsika species (bootstrap support 69\%; no cox1 sequences were available for $P$. homalorhina from Ankarana which in a previous study was the sister taxon of P. hordiesi, see Jackman et al. 2008). All studied species and candidate species of Paroedura included in the cox 1 data set were differentiated by very high pairwise uncorrected distances. $P$. hordiesi differed from its Nosy Hara sister lineage by a p-distance of $16.3-16.5 \%$, and from all other Paroedura including the relatively distantly related $P$. karstophila by $>20 \%$. Two samples sequenced from the Tsingy de Namoroka, the type locality of P. karstophila, were sister to each other but showed a substantial divergence of $15.9 \%$ cox 1 p-distance, suggesting that possibly two cryptic species may be hiding under the name $P$. karstophila in this karstic massif. The sample from Ankarafantsika ( $P$. sp. Ankarafantsika in Fig. 1), identified in Jackman et al. (2008) as P. karstophila, in fact belongs to yet another, undescribed species according to our subsequent comparisons and is only distantly related to P. karstophila (Fig. 1). The DNA barcoding voucher sequence for the karyotype of $P$. karstophila (Koubová et al. 2014) is identical to our sequences of $P$. hordiesi, suggesting that the karyotype description in this paper refers to our new species rather than to P. karstophila.

\section{Description of a new species}

\section{Paroedura hordiesi sp. n.}

http://zoobank.org/8F5AA095-C68A-43E6-BCF8-4A02815A693F Figs 2-4, Table 1

Remarks. This species has been treated or figured under the name Paroedura homalorhinus (Henkel and Schmidt 


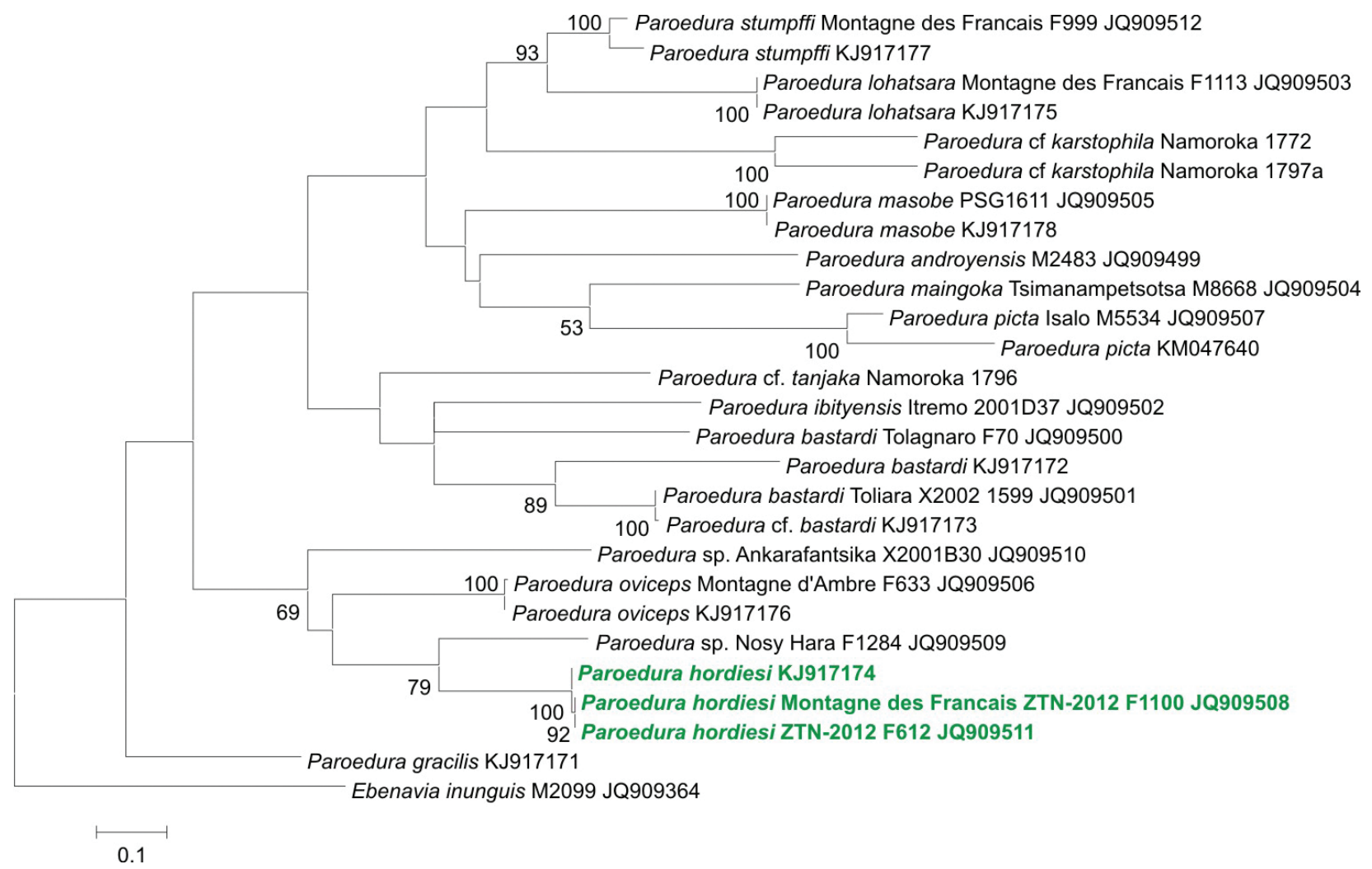

Figure 1. Maximum Likelihood tree inferred from $664 \mathrm{bp}$ of the mitochondrial cytochrome oxidase subunit 1 (cox1) gene, showing the differentiation between Paroedura species. Note that this single-gene tree is not suitable to reconstruct the basal relationships of these geckos but is rather shown to document the large genetic divergences among all of them, and of $P$. hordiesi to its relatives. Numbers behind species names are sample numbers as given in Nagy et al. (2012) and Koubová et al. (2014), as well as GenBank accession numbers of the respective sequences.

1995), Paroedura karstophila (Glaw et al. 2001), Paroedura sp. "Montagne des Français" (Glaw and Vences 2007), Paroedura sp. (D’Cruze et al. 2007), Paroedura aff. karstophila (Schönecker 2008), Paroedura cf. karstophila (Megson et al. 2009), Paroedura sp. n. / sp. n. 1 (Jackman et al. 2008 and Nagy et al. 2012). Its karyotype $(2 \mathrm{n}=36)$ has been described under the names Paroedura sp. n. I 'Montagne des Français' (Aprea et al. 2013) and Paroedura karstophila (Koubová et al. 2014). DNA-sequences of this species have been published in Jackman et al. (2008), Aprea et al. (2013), and Koubová et al. (2014).

Holotype. ZSM 342/2004 (field number FGZC 639), adult male with (broken) original tail and everted hemipenes, collected at Montagne des Français $\left(12^{\circ} 19^{\prime} 34^{\prime \prime} \mathrm{S}\right.$, 4920‘09“"E, $334 \mathrm{~m}$ above sea level), Antsiranana Province, north Madagascar, on 18 February 2004 by F. Glaw, M. Puente and R. Randrianiaina. GenBank accession numbers for sequences of the holotype (Jackman et al. 2008): EF536213 (ND2), EF536239 (ND4), EF536165 (RAG1) and EF536189 (PDC).

Paratypes. All paratypes were collected in the "tsingy" limestone massif at Montagne des Français, Antsiranana province, north Madagascar. Specimens were collected on the tsingy outcrops along the way between the Hotel “Kings Lodge" (12 $18^{\circ} 44,8^{\prime}$ 'S, 49²0'22,6' E, $10 \mathrm{~m}$ a.s.l.) and the remains of the French Fort $\left(12^{\circ} 19^{\prime} 34^{\prime}\right.$ 'S, $49^{\circ} 20^{\prime} 09^{\prime}$ 'E, $334 \mathrm{~m}$ ), except where other locality information and coordinates are given in the following: UADBA uncatalogued (FG/MV 2000-317), sex unknown, and ZSM 531/2000 (FG/MV 2000-316), adult male with everted hemipenes, both collected on 14 March 2000 by F. Glaw, K. Glaw and M. Vences; ZSM 532/2000 (no field number), adult female, collected on 21 March 2000 by F. Glaw and K. Glaw; ZSM 1108/2003 (no field number), adult female, collected on ca. 20 February 2003 by F. Glaw and R. D. Randrianiaina; ZSM 337/2004 (FGZC 634), subadult, and ZSM 338/2004 (FGZC 635), subadult, both collected at $12^{\circ} 19^{\prime} 34^{\prime \prime} \mathrm{S}, 49^{\circ} 20^{\prime} 09^{\prime \prime} \mathrm{E}, 334 \mathrm{~m}$ a.s.1., on 23 February 2004 by F. Glaw, M. Puente and R. D. Randrianiaina; ZSM 339/2004 (FGZC 636), adult female, ZSM 340/2004 (FGZC 637), adult female, ZSM 341/2004 (FGZC 638), adult female [original tail broken], all three with same data as holotype; ZSM 343/2004 (FGZC 640), adult male without tail, and ZSM 350/2004 (FGZC 647), adult female, both without reliable locality and collection data, but most likely with same data as holotype; UADBA uncatalogued (FGZC 612), sex unknown, collected at $12^{\circ} 19^{\prime} 34^{\prime \prime} \mathrm{S}, 49^{\circ} 20^{\circ} 09^{\prime \prime} \mathrm{E}, 334 \mathrm{~m}$ a.s.1., on 20-28 February 2004 by F. Glaw, M. Puente and R. D. Randrianiaina; ZSM 352/2004 (FGZC 649), adult, and ZSM 353/2004 (FGZC 650), adult female, both collected at $12^{\circ} 19^{\circ} 34^{\prime \prime} \mathrm{S}, 49^{\circ} 20^{\circ} 09^{\prime \prime} \mathrm{E}, 334 \mathrm{~m}$ a.s.1., 

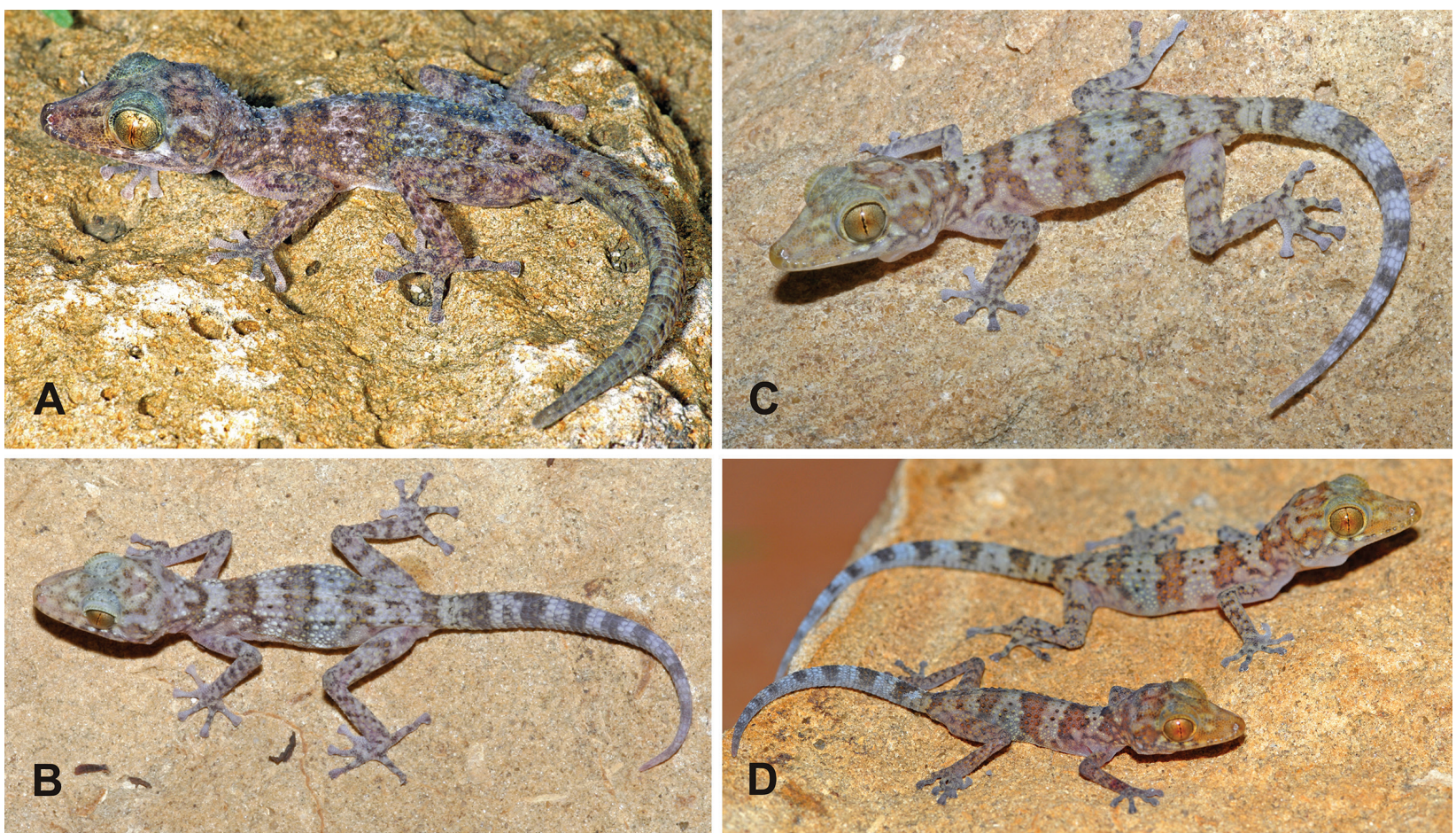

Figure 2. Paratypes of Paroedura hordiesi: (A) adult male ZSM 531/2000 (SVL $53.5 \mathrm{~mm}$ ) in dorsolateral view; (B) adult female ZSM 2113/2007 (SVL $46.1 \mathrm{~mm}$ ) in dorsal view; (C) subadult ZSM 2107/2007 in lateral view; (D) juvenile (ZSM 2106/2007, SVL $28.1 \mathrm{~mm}$ ) and subadult (ZSM 2107/2007, SVL $35.2 \mathrm{~mm}$ ) in dorsolateral view.

on 18-23 February 2004 by F. Glaw, M. Puente and R. D. Randrianiaina; UADBA-R 70183 (FGZC 1109), adult male with everted hemipenes, UADBA-R 70185 (FGZC 1112), male, UADBA-R 70184 (FGZC 1114), adult female, ZSM 2106/2007 (FGZC 1099), juvenile, ZSM 2107/2007 (FGZC 1100), juvenile, ZSM 2113/2007 (FGZC 1115), adult female, all six collected around the remains of the French Fort (12 ${ }^{\circ} 19^{\prime} 33^{\prime}$ 'S , 49 $20^{\prime} 17^{\prime}$ 'E), collected on 27 February 2007 by P. Bora, H. Enting, F. Glaw, A. Knoll and J. Köhler; UADBA-R 70281 (FGZC 1659), sex unknown, ZSM 1530/2008 (FGZC 1660), adult female, both collected in the cave between Andavakoera and remains of French Fort, on 16 February 2008 by M. Franzen, F. Glaw, J. Köhler and Z. T. Nagy.

Diagnosis. Paroedura hordiesi sp. n. is a medium-sized species (SVL up to $58 \mathrm{~mm}$, tail length up to $53 \mathrm{~mm}$ ), having moderately prominent dorsal tubercles disposed into moderately distinct, and generally regular longitudinal rows and an original tail with no spines.

The new species can be easily attributed to the genus Paroedura based on its nested phylogenetic position within the genus (Jackman et al. 2008) and its morphological similarity to other Paroedura species, especially concerning the ventral structure of their fingers and toes which comprise a pair of squarish terminal adhesive pads. Among Malagasy geckos this terminal toe structure is only found in Paroedura and the related genus Ebenavia (Glaw \& Vences, 2007). The latter genus can be easily distinguished from Paroedura by its much narrower and strongly pointed head, its elongated body, and smaller size.
Comparisons. The new species can be distinguished from the 17 other currently recognized Paroedura species (including the three available junior synonyms in the genus) as follows: From $P$. androyensis, $P$. bastardi, $P$. ibityensis, $P$. lohatsara, $P$. maingoka, $P$. picta, and $P$. vahiny by having the nostril in contact with the rostral scale; from $P$. gracilis by absence of a raised vertebral ridge on the body and shorter forelimbs which are not extending forward beyond tip of snout; from $P$. masobe by much smaller size (SVL up to $58 \mathrm{~mm}$ versus 107 $\mathrm{mm}$ ), much smaller eyes with a pigmented iris (versus black iris) and absence of a dorsal row of paired spines on the tail; from the two Comoroan species $P$. sanctijohannis and $P$. stellata by slightly smaller size (SVL up to $58 \mathrm{~mm}$ versus $68 \mathrm{~mm}$ and $62 \mathrm{~mm}$, respectively) and absence of whorls with distinct spiny tubercles of the original tail; from the syntopically distributed $P$. stumpffi by smaller size (SVL up to $58 \mathrm{~mm}$ versus 70 $\mathrm{mm}$ ) and absence of whorls with distinct spiny tubercles of the original tail; from $P$. tanjaka by much smaller size (SVL up to $58 \mathrm{~mm}$ versus $102 \mathrm{~mm}$ ) and absence of whorls with distinct spiny tubercles of the original tail; from $P$. vazimba by larger size (SVL up to $58 \mathrm{~mm}$ versus $49 \mathrm{~mm}$ ) and absence of whorls with distinct spines of the original tail; from $P$. oviceps from its type locality Nosy Be by smaller size (SVL up to $58 \mathrm{~mm}$ versus 69 $\mathrm{mm}$ ) and rather regularly arranged tubercle rows on the back (versus rather irregular rows of tubercles); from $P$. karstophila by the absence of whorls with distinct spiny tubercles of the original tail (and by a smoother regenerated tail, see Nussbaum and Raxworthy 2000) and by 
Table 1. Morphometric and meristic variation of several type specimens of Paroedura hordiesi from the type locality Montagne des Français. Abbreviations for measurements and counts (see Materials and Methods for other abbreviations): ZSM = Zoologische Staatssammlung München; SVL = snout-vent length; TL = tail length; HL = maximum head length (from tip of snout to posterior margin of ear); $\mathrm{HW}=$ maximum head width, at widest point; $\mathrm{HH}=$ maximum head height; $\mathrm{AGL}=$ axilla-groin distance; $\mathrm{ED}=$ maximum eye diameter; $\mathrm{EO}=$ maximum ear opening diameter; $\mathrm{FOL}=$ forelimb length, from axilla to tip of longest finger; $\mathrm{HIL}=$ hindlimb length, from groin to tip of longest toe; $\mathrm{SPL}=$ number of supralabial scales; IFL = number of infralabial scales; NAS $=$ number of nasals in direction from rostral to labial including nasorostrals, supranasals, postnasals; IN = number of internasals; IO $=$ number of interorbitals; PM = number of postmentals; SLM4 = number of subdigital lamellae on fourth digit of manus; SLP4 = number of subdigital lamellae on fourth toe of pes; PCT = number of postcloacal tubercles; TLT = number of tubercle rows on tail. Counts are listed left-right. All measurements in Tables 1 and 2 were taken by H. Rösler with a caliper to the nearest $0.1 \mathrm{~mm}$. HT = holotype, $\mathrm{PT}=$ paratype, $\mathrm{F}=$ female, $\mathrm{M}=$ male, $\mathrm{SA}=$ subadult.

\begin{tabular}{c|c|c|c|c|c|c|c|c|c|c}
\hline ZSM & $\mathbf{3 5 2 / 2 0 0 4}$ & $\mathbf{3 5 3 / 2 0 0 4}$ & $\mathbf{3 4 0 / 2 0 0 4}$ & $\mathbf{3 5 0 / 2 0 0 4}$ & $\mathbf{3 3 9 / 2 0 0 4}$ & $\mathbf{3 4 1 / 2 0 0 4}$ & $\mathbf{3 3 8 / 2 0 0 4}$ & $\mathbf{3 3 7 / 2 0 0 4}$ & $\mathbf{3 4 2 / 2 0 0 4}$ & $\mathbf{3 4 3 / 2 0 0 4}$ \\
\hline $\begin{array}{c}\text { Type } \\
\text { status }\end{array}$ & $\mathrm{PT}$ & $\mathrm{PT}$ & $\mathrm{PT}$ & $\mathrm{PT}$ & $\mathrm{PT}$ & $\mathrm{PT}$ & $\mathrm{PT}$ & $\mathrm{PT}$ & HT & PT \\
\hline Sex & $\mathrm{F}$ & $\mathrm{F}$ & $\mathrm{F}$ & $\mathrm{F}$ & $\mathrm{F}$ & $\mathrm{F}$ & $\mathrm{SA} \mathrm{F}$ & $\mathrm{SA}$ & $\mathrm{M}$ & $\mathrm{M}$ \\
\hline SVL & 56.0 & 55.0 & 56.0 & 54.5 & 58.0 & 57.3 & 43.5 & 43.0 & 52.6 & 51.8 \\
\hline TL & & 48.5 & & & & 53.0 & & & 51.0 & \\
\hline HL & 16.7 & 17.0 & 17.0 & 16.4 & 18.7 & 18.0 & 14.9 & 14.8 & 16.3 & 17.0 \\
\hline HW & 12.8 & 12.1 & 12.3 & 10.8 & 12.5 & 12.4 & 9.6 & 9.1 & 10.9 & 11.2 \\
\hline HH & 8.0 & 7.1 & 7.2 & 6.3 & 7.4 & 6.6 & 5.8 & 5.1 & 6.4 & 5.7 \\
\hline AGL & 25.0 & 22.0 & 23.0 & 22.8 & 23.0 & 23.7 & 17.0 & 18.1 & 21.7 & 21.0 \\
\hline ED & 3.1 & 3.4 & 3.5 & 3.3 & 4.6 & 4.7 & 4.1 & 4.4 & 3.5 & 4.5 \\
\hline EO & 2.2 & 1.9 & 1.7 & 1.9 & 1.8 & 1.8 & 1.5 & 1.5 & 1.7 & \\
\hline FOL & 20.0 & 19.8 & 20.2 & 20.0 & 20.6 & 21.2 & 16.2 & 17.4 & 18.6 & 18.7 \\
\hline HIL & 27.0 & 25.1 & 28.8 & 28.7 & 28.6 & 30.0 & 24.5 & 24.4 & 27.5 & 26.4 \\
\hline SVL:HIL & 2.07 & 2.19 & 1.94 & 1.90 & 2.03 & 1.91 & 1.78 & 1.76 & 1.91 & 1.96 \\
\hline SPL & $15-15$ & $15-14$ & $15-15$ & $14-15$ & $16-15$ & $15-14$ & $15-15$ & $15-14$ & $14-14$ & $15-14$ \\
\hline IFL & $13-13$ & $13-13$ & $12-13$ & $14-13$ & $13-13$ & $14-13$ & $14-13$ & n.a.-12 & $13-12$ & $14-14$ \\
\hline NAS & $5-5$ & $5-5$ & $5-5$ & 4 & $5-5$ & $5-5$ & $5-5$ & $5-5$ & $5-5$ & $5-5$ \\
\hline IN & 1 & 1 & 1 & 1 & 1 & 1 & 1 & 1 & 1 & 1 \\
\hline IO & 6 & 6 & 6 & 7 & 7 & 7 & 8 & 6 & 7 & 6 \\
\hline PM & 2 & 2 & 2 & 2 & 2 & 2 & 2 & & 2 & 2 \\
\hline SLM4 & $13-13$ & $14-14$ & $15-16$ & 15 & $17-15$ & $16-16$ & $15-15$ & & $15-15$ & 15 \\
\hline SLP4 & $16-18$ & $17-18$ & $19-19$ & $18-18$ & $20-20$ & $18-18$ & $18-17$ & & $17-18$ & $19-19$ \\
\hline PCT & $1-1$ & $1-1$ & $1-1$ & & $1-1$ & $1-1$ & $1-1$ & $1-1$ & $1-1$ & $1-1$ \\
\hline TLT & & 7 & & & & 6 & & & 7 & \\
\hline & & & & & & & & & \\
\hline
\end{tabular}

colouration (see Fig. 2 versus Fig. 5); and from its close relative $P$. homalorhina (Jackman et al. 2008) by shorter limbs (finger tips reach the anterior margin of eye versus snout tip when forelimbs are adpressed along the body), slightly smaller size (SVL up to $58 \mathrm{~mm}$ versus $65 \mathrm{~mm}$, see Table 2), distinct and generally regularly arranged tubercles rows on the back (versus less distinct and less regular rows), and a more slender habitus (see Fig. 2 versus Fig. 5). In addition, Paroedura hordiesi can be easily distinguished from most other Paroedura species (P. androyensis, $P$. bastardi, $P$. gracilis, $P$. ibityensis, $P$. lohatsara, $P$. maingoka, $P$. masobe, $P$. oviceps, $P$. picta, $P$. sanctijohannis, $P$. stellata, $P$. stumpffi, $P$. tanjaka, $P$. vahiny and $P$. vazimba) by adult colouration in life (see colour photographs in Glaw and Vences 2007, Schönecker 2008, Hawlitschek and Glaw 2013) and from $P$. androyensis, P. bastardi, P. gracilis, P. homalorhina, P. ibityensis, $P$. lohatsara, $P$. maingoka, $P$. masobe, $P$. picta, $P$. sanctijohannis, $P$. stellata, $P$. stumpffi, $P$. tanjaka, and $P$. vazimba by juvenile colouration (Glaw and Vences 2007, Schönecker 2008, Hawlitschek and Glaw
2013, FG pers. obs.; juvenile colouration of the other species still unknown). Genetically, $P$. hordiesi can be distinguished from all other species in the genus by its molecular differentiation in mitochondrial and nuclear genes (Jackman et al. 2008, Nagy et al. 2012, Hawlitschek and Glaw 2013, Fig. 1) except for P. vahiny for which DNA sequences are not yet available.

Description of the holotype. SVL $52.6 \mathrm{~mm}$, further measurements and counts are given in Table 1. Holotype in good condition, with complete but broken original tail and everted hemipenes. Head distinctly wider than neck and wider than body. Snout angled downward to tip, slight depression between poorly developed canthal ridges. Ear opening is a vertical slit. Original tail slightly shorter than snout-vent length, nearly round in cross section in its proximal part, laterally compressed in its distal half, with sharply pointed tip; ventral pygal section with pair of postcloacal sacs. Digits moderately expanded at tips. Rostral scale rectangular, much wider than tall and wider than mental. Nostril in contact with 


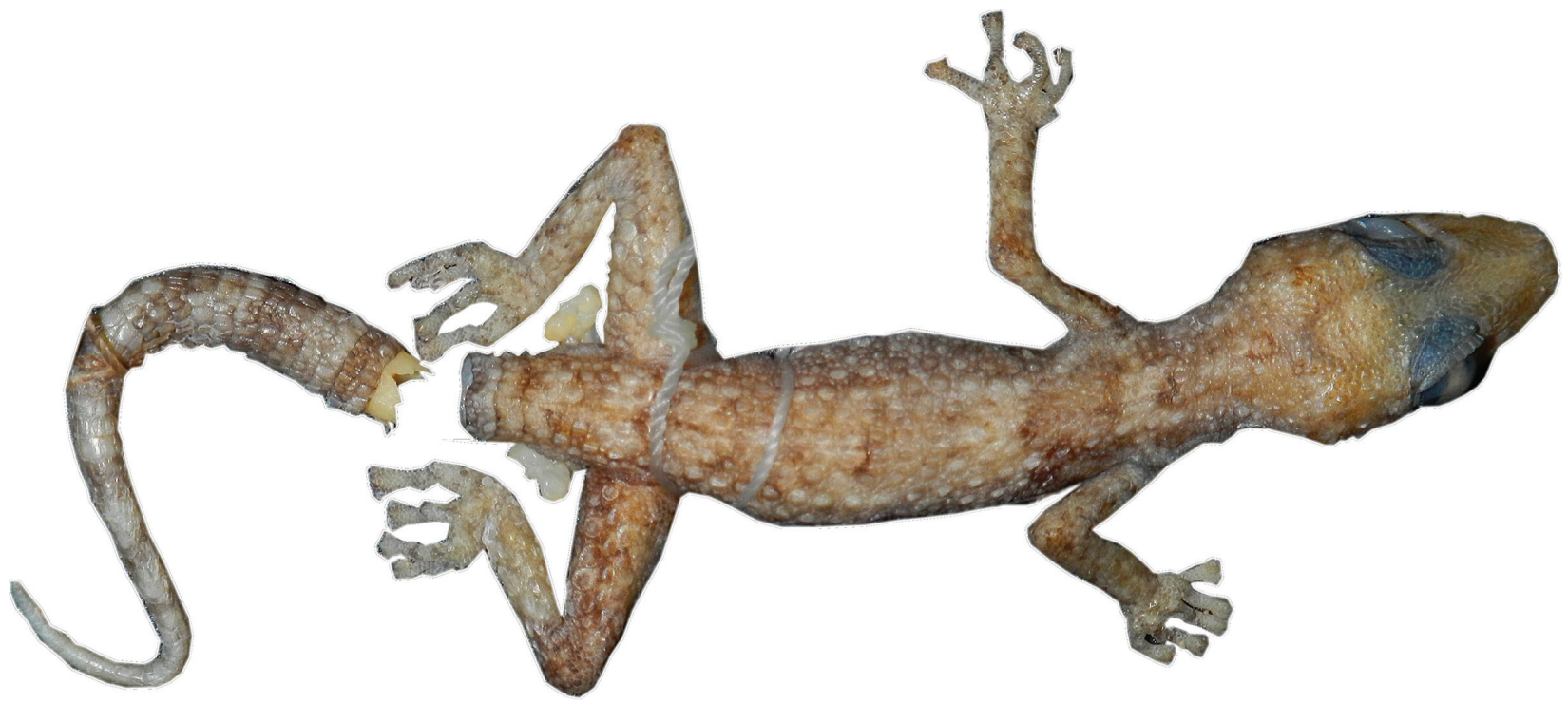

Figure 3. Dorsal view of the male holotype of Paroedura hordiesi in preservative (ZSM 342/2004).
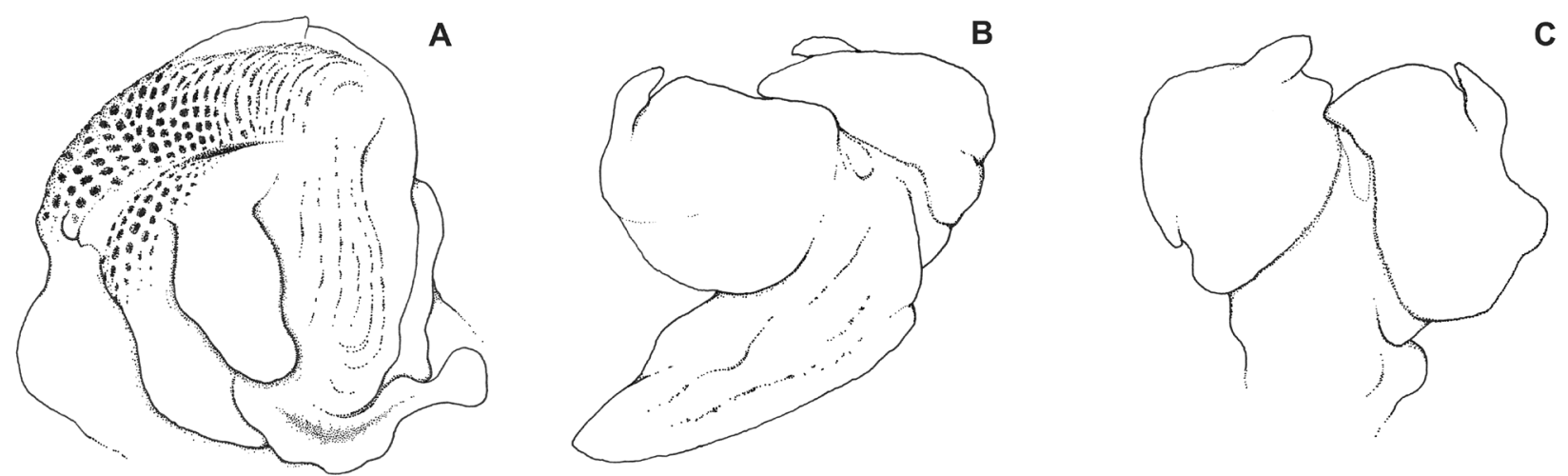

Figure 4. Drawings of hemipenis of Paroedura hordiesi (ZSM 343/2004): (A) asulcal view; (B) lateral view; (C) detailed view on cranial lobe.

rostral, first supralabial, and five further scales. First supralabial largest, labials smooth. Snout and interorbital scales juxtaposed, some raised, some scales in front of orbits tuberculate, as are some larger lateral occipital scales. Dorsolateral neck and body scales very heterogeneous with about eight partly poorly recognizable longitudinal rows at midbody of enlarged tubercles; enlarged tubercles separated partly by small flat scales and smaller tubercles. Dorsal scales of forelimbs mostly flat. Dorsal scales of hindlimbs large and tuberculate, much smaller above knee. Ventral scales of forelimbs slightly smaller than surrounding ventral scales of the body. Dorsal pygal scales like dorsal body scales; lateroventral pygals tuberculate. Tail scales flat, tail segments without any transverse row of spiny tubercles. Mental triangular, bordered posteriorly by a pair of elongate, irregular hexagonal postmentals. Postmentals contact mental, first and second infralabial, one enlarged lateral gular, one smaller posterolateral gular, and one larger central gular. First three infralabials not significantly larger than others. Gulars small, granular. Ventrals of chest and abdomen flat. Proximal subdigitals in rows of 2-3. Pair of squarish, terminal pads. Claws curving downwards between terminal pads of digits.

Colour after 10 years in alcohol (Fig 3): head dorsally beige with almost no recognizable pattern except a whitish dorsolateral spot above each ear opening and a well-defined blackish area above each eye which represents, however, no pigmentation of the skin, but is due to the blackish eyeball shining through the skin. Dorsum greyish with four poorly defined beige spots on the back which are the remains of dorsal crossbands: one distinct spot between the forelimbs, two poorly recognizable spots on the back between forelimbs and hindlimbs, and a fourth poorly recognizable spot between the hindlimbs. Dorsal surfaces of forelimbs and hindlimbs marbled with beige and grey. Flanks with similar colour as dorsum, but without any recognizable traces of light crossbands. Tail dorsally with whitish-grey and brown alternating transverse bands which are poorly delimited in the distal portion of the tail. Throat, chest, venter, ventral parts of forelimbs and hindlimbs and ventral side of tail whitish. Iris dark grey, pupil white. Colour of holotype in life unknown (no colour photographs available). 

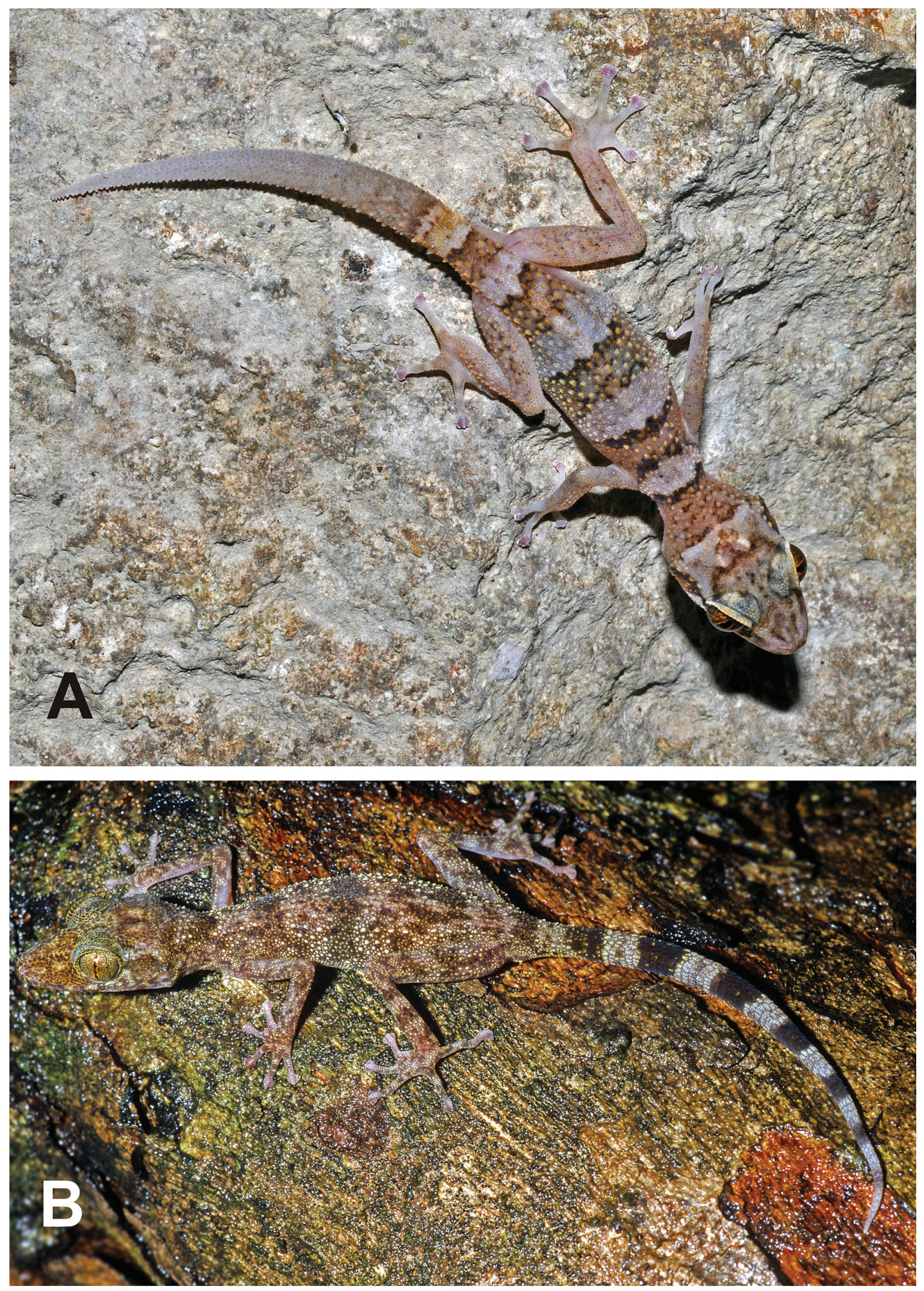

Figure 5. Paroedura karstophila from its type locality Tsingy de Namoroka (A), observed in the night of 10 September 2012 around 22:50 (not collected), and P. homalorhina from its type locality Ankarana (B). 
Table 2. Morphometric and meristic variation of Paroedura homalorhina from the type locality Ankarana. See Table 1 for abbreviations and further details.

\begin{tabular}{c|c|c|c|c|c|c|c|c}
\hline ZSM & $\mathbf{3 4 5 / 2 0 0 4}$ & $\mathbf{3 4 7 / 2 0 0 4}$ & $\mathbf{3 4 8 / 2 0 0 4}$ & $\mathbf{3 4 6 / 2 0 0 4}$ & $\mathbf{3 4 9 / 2 0 0 4}$ & $\mathbf{3 4 4 / 2 0 0 4}$ & $\mathbf{7 6 8 / 2 0 0 3}$ & $\mathbf{7 8 1 / 2 0 0 3}$ \\
\hline Sex & $\mathrm{M}$ & $\mathrm{F}$ & $\mathrm{F}$ & $\mathrm{M}$ & $\mathrm{F}$ & $\mathrm{F}$ & $\mathrm{F}$ & $\mathrm{M}$ \\
\hline SVL & 64.8 & 58.6 & 58.8 & 61.5 & 61.3 & 61.7 & 60.4 & 62.8 \\
\hline TL & 68.0 & 60.0 & & & & & 61.7 & \\
\hline $\mathbf{H L}$ & 19.6 & 17.6 & 17.7 & 19.0 & 17.8 & 19.2 & 18.3 & 18.7 \\
\hline $\mathbf{H W}$ & 12.6 & 12.0 & 11.4 & 12.9 & 12.2 & 12.6 & 11.3 & 12.9 \\
\hline HH & 7.3 & 7.2 & 6.4 & 7.2 & 7.0 & 7.5 & 7.2 & 7.0 \\
\hline AGL & 26.8 & 24.0 & 23.0 & 27.8 & 28.0 & 27.1 & 26.4 & 24.4 \\
\hline ED & 3.8 & 3.5 & 4.3 & 4.3 & 3.8 & 4.0 & 4.7 & 4.4 \\
\hline EO & 1.6 & 1.7 & 1.5 & 1.6 & 1.8 & 1.6 & 1.7 & 1.6 \\
\hline FOL & 23.9 & 23.8 & 22.4 & 25.2 & 21.7 & 25.4 & 24.1 & 25.7 \\
\hline HIL & 36.4 & 36.6 & 33.0 & 39.2 & 35.3 & 33.0 & 34.5 & 35.8 \\
\hline SVL:HIL & 1.78 & 1.60 & 1.78 & 1.57 & 1.74 & 1.87 & 1.75 & 1.75 \\
\hline SPL & $15-14$ & $16-15$ & $16-15$ & $15-15$ & $14-14$ & $15-15$ & $15-14$ & $15-16$ \\
\hline IFL & $13-13$ & $13-13$ & $12-14$ & $13-12$ & $14-13$ & $12-13$ & $13-12$ & $13-12$ \\
\hline NAS & $5-5$ & $5-5$ & $5-5$ & $5-5$ & $5-6$ & $6-6$ & $6-6$ & $5-5$ \\
\hline IN & 1 & 1 & 1 & 1 & 1 & 1 & 1 & 1 \\
\hline IO & 6 & 6 & 6 & 6 & 6 & 6 & & 6 \\
\hline PM & 2 & 2 & 2 & 2 & 2 & 2 & 2 & 2 \\
\hline SLM4 & $16-16$ & $15-16$ & $16-16$ & $16-16$ & $17-17$ & n.a.-17 & $16-16$ & $15-14$ \\
\hline SLP4 & $18-19$ & $18-19$ & $18-17$ & $20-20$ & $19-20$ & $19-19$ & $19-19$ & $19-18$ \\
\hline PCT & $1-1$ & $1-1$ & $1-1$ & $1-1$ & $1-1$ & $1-1$ & $1-1$ & $1-1$ \\
\hline TLT & 3 & 5 & & & & & 2 & \\
\hline
\end{tabular}

Variation. Morphometric and meristic variation of ten specimens of the type series is summarized in Table 1, but there is also a remarkable individual variation in dorsal colouration and pattern (Fig. 2). Paratype ZSM 2106/2007, the smallest known juvenile (SVL $28.1 \mathrm{~mm}$, tail length $25.2 \mathrm{~mm}$ ), shows a moderately distinct juvenile colouration both in life (Fig. 2) and in preservative consisting of four light crossbands on the back between the insertion of forelimbs and the insertion of hindlimbs. A similarly distinct banding on body and original tail is still visible in the larger juvenile paratype ZSM 2107/2007 (Fig. 2, SVL $35.2 \mathrm{~mm}$, tail length $34.7 \mathrm{~mm}$ ). Although the juvenile colouration is distinct compared to most adults, it is less colourful and less contrasting in comparison with many other Paroedura species. The adult paratypes usually have a less distinct dorsal colour pattern than the juveniles, ranging from poorly recognizable (e. g. ZSM 532/2000) to distinct and well delimited (e. g. ZSM 531/2000) after 14 years in alcohol. Additional photographs of living individuals are provided in Henkel and Schmidt (1995), Glaw and Vences (2007), and Schönecker (2008). Most of the adult type specimens have a regenerated tail (without distinct transversal banding of dark and white), indicating a high pressure by predation or intraspecific aggression.

Hemipenis. The following description is based on the everted right organ of ZSM 343/2004 (Fig. 4). Hemipenis medium-sized (total length $6.4 \mathrm{~mm}$, width at apex $4.5 \mathrm{~mm}$ ), apex divided in two lobes. Sulcus spermaticus forms an S-shaped, narrow and deep groove, bordered by moderately distinct lips reaching the apex. On the apex, the sulcus is becoming broader and divides in two branches. A horn-like apical cone is present in the center of each lobe. Calyces on the apex are only present at the border of the lobes. The hemipenes of the holotype (ZSM $342 / 2004)$ are virtually identical in every respect.

Habitat and habits. Paroedura hordiesi was observed multiple times at night in karstic dry forest in the rainy season, mainly climbing on karstic rocks and the ruins of an old fort. It was found in close syntopy with $P$. lohatsara in the karstic limestone areas, whereas $P$. stumpffi was only encountered on the slope between the massif and the sea, in areas without karstic formations.

Etymology. The specific name is dedicated to Freddy Hordies, in recognition of his support for biodiversity research and conservation through the BIOPAT initiative.

Distribution and conservation status. Paroedura hordiesi is reliably known only from the recently established nature reserve of Montagne des Français. The species possibly also occurs at Ampombofofo, ca. $25 \mathrm{~km}$ north of this massif (Megson et al. 2009: ZSM 1531/2008), but the identity of this population needs further study as molecular data are not available thus far. Surveys in other limestone areas of northern Madagascar revealed a superficially similar Paroedura at Nosy Hara (Metcalf et al. 2007) which is, however, strongly differentiated by colouration (see photo in Glaw and Vences 2007) and mitochondrial DNA sequences (Fig. 1 and Nagy et al. 2012), and is therefore considered a further undescribed candi- 
date species. The Ankarana massif is known to harbour $P$. homalorhina, P. karstophila, and P. stumpffi (Nussbaum and Raxworthy 2000, Raselimanana 2008). Our own surveys in Ankarana revealed only $P$. homalorhina and $P$. stumpffi and we consider the occurrence of $P$. hordies $i$ unlikely in this massif. Rakotondravony (2006a) found Paroedura sp. at Binara in the Loky-Manambato region which potentially could refer to $P$. hordiesi, but the identity of this record remains to be studied. No unidentified Paroedura species was found at Analamera (Rakotondravony 2006b). Thus current evidence suggests that $P$. hordiesi is microendemic of Montagne des Français and perhaps the adjacent Ampombofofo region.

For consistency with the IUCN Red List Assessment for Paroedura lohatsara (Raxworthy et al. 2011) and other potential microendemic species of the Montagne des Français region, we suggest a classification as "Critically Endangered" on the basis that $P$. hordiesi has an extent of occurrence of at most $50 \mathrm{~km}^{2}$, it is known from a single location, and there is a continuing decline in the extent and quality of its habitat.

\section{Discussion}

With the description of Paroedura hordiesi we add a further, probably microendemic new species to the herpetofauna of Montagne des Français. Although this population is already known for approximately 20 years, several factors have hampered the clarification of its identity, including the variability in colouration and in distinctiveness of longitudinal rows of dorsal tubercles of $P$. hordiesi, $P$. homalorhina and $P$. karstophila, the existence of several undescribed species with similar key characters, the rarity of individuals with an original tail, and the absence of genetic data and colour photographs reliably referable to $P$. karstophila. This situation has led to substantial uncertainty about the correct name for the species from Montagne des Français, as is reflected by the different preliminary names that have been used for this species in the literature (see above). DNA sequences are now available from two P. karstophila-like specimens from the type locality Namoroka (Fig. 1). These strongly differ from each other, suggesting that $P$. karstophila is possibly a composite taxon including two cryptic species which occur in syntopy at Namoroka. Although the identity of P. karstophila remains to be further studied, we have little doubts that one of the two Namoroka lineages will turn out to correspond to this taxon.

Due to PCR failure with universal reptile primers (Nagy et al. 2012), no cox1 sequences are available for several species of Paroedura, including P. homalorhina which was sister to $P$. hordiesi in the study of Jackman et al. (2008; as $P$. sp. n.). On the other hand, the new species from Nosy Hara and $P$. karstophila have not yet been sequenced for the genes used by Jackman et al. (2008). This unfortunate lack of overlap of the two molecular data sets, to be remedied by future sequencing efforts, hampers our ability to determine whether $P$. hordiesi is more closely related to $P$. homalorhina, or to the undescribed species from Nosy Hara. It does not, however, compromise our taxonomic conclusion of $P$. hordiesi being a valid species differentiated from both these close relatives by a substantial genetic divergence and morphological characters.

Paroedura hordiesi is a typical example of a microendemic karst specialist of an isolated habitat island that apparently has lost its ability to survive outside its special habitat and thus has lost the genetic exchange with populations from neighboured karstic massifs. Although the surrounding massifs are only separated by several kilometers of grassland or other non-karstic habitats, they are often populated by different species which might have evolved in isolation for millions of years. The cox1 data presented in Fig. 1 suggest that the undescribed Paroedura species from the island Nosy Hara is a close relative of $P$. hordiesi. The two species differ by a substantial genetic distance, and distinctly by their colouration (see photographs in Glaw and Vences 2007), although the distance between this island and Montagne des Français is just about $35 \mathrm{~km}$. The distance between Montagne des Français and Ankarana is approximately $50 \mathrm{~km}$, yet the latter massif is populated by $P$. homalorhina, the second close relative of $P$. hordiesi (see discussion in previous paragraph). Similar patterns of microendemism and comparable phylogenetic relationships have been found in dwarf chameleons of the genus Brookesia (Glaw et al. 2012), in a clade of dwarf frogs of the genus Stumpffia (Köhler et al. 2010a), and in lizards of the genus Zonosaurus (Raselimanana et al. 2009, Recknagel et al. 2013), suggesting that similar vicariant processes among karstic habitat islands might have affected these groups of organisms in the far north of Madagascar. The karstic massifs might have provided sufficient resources and protection from desiccation during periods of drier climate to allow the long-term survival of these populations, finally leading to completed speciation. The evolution and long-term survival of these microendemic species suggests rather stable conditions without catastrophic events over very long time periods. The apparent lack of gene flow among the karstic habitat islands also suggests a limited dispersal capacity of karst specialists across the non-karstic interspersed matrix.

\section{Acknowledgements}

We are very grateful to Parfait Bora, Hildegard Enting, Michael Franzen, Kathrin Glaw, Angelika Knoll, Steven Megson, Zoltan T. Nagy, Marta Puente, Roger-Daniel Randrianiaina, Angelin Razafimanantsoa and the team of the Kings Lodge for their help in the field, to York Pareik for logistic support, and to two anonymous reviewers for their helpful comments on the manuscript. Special thanks go to Freddy Hordies for his dedication for biodiversity research and conservation and his patience. The research in Madagascar was made possible 
by a cooperation accord between the UADBA and the ZSM. Malagasy authorities are acknowledged for collection and export permits. The research of F. Glaw was supported by the "Deutsche Forschungsgemeinschaft" (grant no. GL 314/1) and the European Association of Zoos and Aquaria (EAZA). Fieldwork of I. Ineich was made possible with the help of Ewe Madagascar for logistical support (Marc Gansuana), La Colas and the Société Aquamas for providing boats, thanks to them. He also wants to thank Lucile Allorge and Thomas Haevermans (MNHN) for scientific organisation, MNHN Labex for providing founds, and the Parc naturel du Namoroka, its guides and the inhabitants of the village of Vilanandro for their useful help.

\section{References}

Andreone F (2004) Crossroads of herpetological diversity: survey work for an integrated conservation of amphibians and reptiles in northern Madagascar. Italian Journal of Zoology, Supplement 2: 229-235. doi: 10.1080/11250000409356640

Angel F (1942) Les lézards de Madagascar. Mémoires de l'Académie Malgache 36: 1-139.

Aprea G, Andreone F, Fulgione D, Petraccioli A, Odierna G (2013) Chromosomal rearrangements occurred repeatedly and independently during species diversification in Malagasy geckos, genus Paroedura. African Zoology 48: 96-108. doi: 10.3377/004.048.0101

Crottini A, Brown JL, Mercurio V, Glaw F, Vences M, Andreone F (2012) Phylogeography of the poison frog Mantella viridis (Amphibia: Mantellidae) reveals chromatic and genetic differentiation across ecotones in northern Madagascar. Journal of Zoological Systematics and Evolutionary Research 50: 305-314. doi: 10.1111/j.1439-0469.2012.00665.x

D’Cruze N, Köhler J, Vences M, Glaw F (2010) A new fat fossorial frog (Microhylidae: Cophylinae: Rhombophryne) from rainforest of the Forêt d'Ambre Special Reserve, northern Madagascar. Herpetologica 66: 182-191. doi: 10.1655/09-008R1.1

D’Cruze N, Sabel J, Green K, Dawson J, Gardner C, Robinson J, Starkie G, Vences M, Glaw F (2007) The first comprehensive survey of amphibians and reptiles at Montagne des Français, Madagascar. Herpetological Conservation and Biology 2: 87-99.

Dixon JR, Kroll JC (1974) Resurrection of the generic name Paroedura for the phyllodactyline geckos of Madagascar, and description of a new species. Copeia 1974: 24-30. doi: 10.2307/1443003

Glaw F, Köhler J, De la Riva I, Vieites DR, Vences M (2010) Integrative taxonomy of Malagasy treefrogs: combination of molecular genetics, bioacoustics and comparative morphology reveals twelve additional species of Boophis. Zootaxa 2383: 1-82.

Glaw F, Köhler J, Townsend TM, Vences M (2012) Rivaling the world's smallest reptiles: Discovery of miniaturized and microendemic new species of leaf chameleons (Brookesia) from northern Madagascar. PLoS ONE 7: e31314. doi: 10.1371/journal.pone.0031314

Glaw F, Kucharzewski C, Köhler J, Vences M, Nagy ZT (2013) Resolving an enigma by integrative taxonomy: Madagascarophis fuchsi (Serpentes: Lamprophiidae), a new opisthoglyphous and microendemic snake from northern Madagascar. Zootaxa 3630: 317-322. doi: 10.11646/zootaxa.3630.2.7
Glaw F, Nagy ZT, Franzen M, Vences M (2007) Molecular phylogeny and systematics of the pseudoxyrhophiine snake genus Liopholidophis (Reptilia, Colubridae): evolution of its exceptional sexual dimorphism and descriptions of new taxa. Zoologica Scripta 36: 291-300. doi: 10.1111/j.1463-6409.2007.00278.x

Glaw F, Vences M (2007) A field guide to the amphibians and reptiles of Madagascar. $3^{\text {rd }}$ edition. Vences and Glaw Verlag, Cologne, 496 pp.

Glaw F, Vences M, Nussbaum RA (2005) A new species of Heteroliodon (Reptilia: Squamata: Colubridae) from Montagne des Français, far northern Madagascar. Herpetologica 61: 275-280. doi: 10.1655/01-101.1

Glaw F, Vences M, Schmidt K (2001) A new species of Paroedura Günther from northern Madagascar (Reptilia, Squamata, Gekkonidae). Spixiana 24: 249-256.

Guibé J (1956) Révision des espèces malgaches du genre Phyllodactylus Gray. Mémoires de l'institut scientifiques de Madagascar (A) 10: 245-250.

Hawlitschek O, Glaw F (2013) The complex colonization history of nocturnal geckos (Paroedura) on the Comoros Archipelago. Zoologica Scripta 42: 135-150. doi: 10.1111/zsc.12001

Henkel FW, Schmidt W (1995) Amphibien und Reptilien Madagaskars, der Maskarenen, Seychellen und Komoren. Ulmer Verlag, Stuttgart, 311 pp.

Jackman TR, Bauer AM, Greenbaum E, Glaw F, Vences M (2008) Molecular phylogenetic relationships among species of the Malagasy-Comoran gecko genus Paroedura (Squamata: Gekkonidae). Molecular Phylogenetics and Evolution 46: 74-81. doi: 10.1016/j. ympev.2007.10.018

Köhler J, Glaw F, Vences M (2008) Two additional treefrogs of the Boophis ulftunni species group (Anura: Mantellidae) discovered in rainforests of northern and south-eastern Madagascar. Zootaxa 1814: 37-48.

Köhler J, Vences M, D’Cruze N, Glaw F (2010a) Giant dwarfs: discovery of a radiation of large-bodied 'stump-toed frogs' from karstic cave environments of northern Madagascar. Journal of Zoology 282: 21-38. doi: 10.1111/j.1469-7998.2010.00708.x

Köhler J, Vences M, Erbacher M, Glaw F (2010b) Systematics of limbless scincid lizards from northern Madagascar: morphology, phylogenetic relationships and implications for classification (Squamata: Scincidae). Organisms, Diversity and Evolution 10: 147-159. doi: 10.1007/s13127-010-0011-5

Koubová M, Johnson Pokorná M, Rovatsos M, Farkačová K, Altmanová M, Kratochvíl L (2014) Sex determination in Madagascar geckos of the genus Paroedura (Squamata: Gekkonidae): are differentiated sex chromosomes indeed so evolutionary stable? Chromosome Research (published online). doi: 10.1007/s10577-014-9430-z

Lavranos JJ, Röösli W, Hoffmann R (2001) Montagne des Français an ultimate paradise in Madagascar. Cactus and Succulent Journal (U.S.) 73: 4-11.

Megson S, Mitchell P, Köhler J, Marsh C, Franzen M, Glaw F, D’Cruze N (2009) A comprehensive survey of amphibians and reptiles in the extreme north of Madagascar. Herpetology Notes 2: 31-44.

Metcalf CJE, Hampson K, Gray A, Andrianirina R (2007) Herpetofaunal assemblages on seven offshore islands of northwestern Madagascar. Tropical Zoology 20: 151-161.

Miralles A, Köhler J, Glaw F, Vences M (2011) A molecular phylogeny of the "Madascincus polleni species complex", with description of a new species of scincid lizard from the coastal dune area of northern Madagascar. Zootaxa 2876: 1-16. 
Nagy ZT, Sonet G, Glaw F, Vences M (2012) First large-scale DNA barcoding assessment of reptiles in the biodiversity hotspot of Madagascar, based on newly designed COI primers. PLoS ONE 7: e34506. doi: 10.1371/journal.pone.0034506

Nussbaum RA, Raxworthy CJ (2000) Systematic revision of the genus Paroedura Günther (Reptilia: Squamata: Gekkonidae), with description of five new species. Miscellaneous Publications Museum of Zoology, University of Michigan 189: 1-26.

Rakotondravony HA (2006a) Patterns de la diversité des reptiles et amphibiens de la région de Loky-Manambato. In: Goodman SM, Wilmé L (Eds) Inventaires de la faune et de la flore du nord de Madagascar dans la région Loky-Manambato, Analamerana et Andavakoera. Recherche pour le Développement, Série Sciences Biologiques 23: 101-148.

Rakotondravony HA (2006b) Reptiles et amphibiens de la Réserve Spéciale d'Analamerana et de la forêt classée d'Andavakoera dans l'extrême Nord de Madagascar. In: Goodman SM, Wilmé L (Eds) Inventaires de la faune et de la flore du nord de Madagascar dans la région Loky-Manambato, Analamerana et Andavakoera. Recherche pour le Développement, Série Sciences Biologiques 23: 149-173.

Ramanamanjato JB, Nussbaum RA, Raxworthy CJ (1999) A new species of Mabuya Fitzinger (Squamata: Scincidae: Lygosominae) from northern Madagascar. Occasional Papers Museum of Zoology, University of Michigan 728: 1-22.

Ranaivoarisoa JF, Zaonarivelo JR, Lei R, Johnson SE, Wyman TM, Mittermeier RA, Louis EE Jr (2013) Rapid survey and assessment of the northern Sportive Lemur, Lepilemur septentrionalis, in northern Madagascar. Primate Conservation 27: 23-31. doi: 10.1896/052.027.0109

Raselimanana AP (2008) Herpétofaune des forêts sèches malgaches. Malagasy Nature 1: 46-75.

Raselimanana AP, Noonan B, Karanth KP, Gauthier J, Yoder AD (2009) Phylogeny and evolution of Malagasy plated lizards. Molecular Phylogenetics and Evolution 50: 336-344. doi: 10.1016/j. ympev.2008.10.004

Raselimanana AP, Raxworthy CJ, Nussbaum RA (2000) A revision of the dwarf Zonosaurus Boulenger (Reptilia: Squamata: Cordylidae) from Madagascar, including descriptions of three new species. Scientific Papers Natural History Museum University of Kansas 18: 1-16.
Ratsoavina FM, Louis EE Jr, Crottini A, Randrianiaina RD, Glaw F, Vences M (2011) A new leaf tailed gecko species from northern Madagascar with a preliminary assessment of molecular and morphological variability in the Uroplatus ebenaui group. Zootaxa 3022: 39-57.

Raxworthy CJ, Nussbaum RA (2006) Six new species of occipital-lobed Calumma chameleons (Squamata: Chamaeleonidae) from montane regions of Madagascar, with a new description and revision of Calumma brevicorne. Copeia 2006: 711-734. doi: 10.1643/0045-8511(2006)6[711:SNSOOC]2.0.CO;2

Raxworthy CJ, Ratsoavina F, Rabibisoa N, Rakotondrazafy NA, Bora P (2011) Paroedura lohatsara. The IUCN Red List of Threatened species. http://www.iucnredlist.org [accessed 12 October 2014]

Recknagel H, Elmer KR, Noonan BP, Raselimanana AP, Meyer A, Vences M (2013) Multi-gene phylogeny of Madagascar's plated lizards, Zonosaurus and Tracheloptychus (Squamata: Gerrhosauridae). Molecular Phylogenetics and Evolution 69: 1215-1221. doi: 10.1016/j.ympev.2013.06.013

Rösler H, Krüger J (1998) Eine neue Unterart von Paroedura bastardi (Mocquard, 1900) (Sauria: Gekkonidae) aus dem zentralen Hochland von Madagaskar. Sauria 20(2): 37-46.

Schönecker P (2008) Geckos of Madagascar, the Seychelles, Comoros and Mascarene Islands. Edition Chimaira, Terralog 12: 1-144.

Tamura K, Peterson D, Peterson N, Stecher G, Nei M, Kumar S (2011) MEGA5: molecular evolutionary genetics analysis using maximum likelihood, evolutionary distance, and maximum parsimony methods. Molecular Biology and Evolution 28: 2731-2739. doi: 10.1093/ molbev/msr121

Vences M, Wollenberg KC, Vieites DR, Lees DC (2009) Madagascar as a model region of species diversification. Trends in Ecology and Evolution 24: 456-465. doi: 10.1016/j.tree.2009.03.011

Wegener JE, Swoboda S, Hawlitschek O, Franzen M, Wallach V, Vences M, Nagy ZT, Hedges SB, Köhler J, Glaw F (2013) Morphological variation and taxonomic reassessment of the endemic Malagasy blind snake family Xenotyphlopidae (Serpentes, Scolecophidia). Spixiana 36: 269-282.

Wilmé L, Goodman SM, Ganzhorn JU (2006) Biogeographic evolution of Madagascar's microendemic biota. Science 312: 1063-1065. doi: 10.1126/science. 1122806 